\title{
PENGGUNAAN MEDIA TIGA DIMENSI DALAM MENINGKATKAN HASIL BELAJAR MATEMATIKA PESERTA DIDIK
}

\author{
Dedy Setyawan \\ Muhammad Fitriadi \\ Universitas Muhammadiyah Palangka raya
}

\begin{abstract}
Abstrak: Penelitian ini bertujuan untuk mengetahui bagaimana peningkatan hasil belajar matematika kelas IV/B SDN-3 Kereng Bangkirai setelah menggunakan media tiga dimensi. Metode yang digunakan peneliti adalah menggunakan rancangan Penelitian Tindakan Kelas (PTK). Populasi penelitian berjumlah 26 peserta didik yang sekaligus dijadikan sebagai sampel penelitian. Teknik analisis data didasarkan pada hasil siklus saat proses pembelajaran. Hasil penelitian menunjukkan bahwa: Penggunaan media tiga dimensi dapat meningkatkan hasil belajar Matematika peserta didik kelas IV/B SDN-3 Kereng Bangkirai tahun pelajaran 2012/2013. Hal ini dapat dibuktikan dengan perolehan nilai rata-rata setiap siklus semakin meningkat. Pada siklus I nilai rata-rata yang diperoleh yaitu 66,06 dengan kriteria tingkat keberhasilan pembelajaran tercapai. Sedangkan pada siklus II nilai rata-rata yang diperoleh 92,31 dengan kriteria tingkat keberhasilan pembelajaran sangat tercapai.
\end{abstract}

Kata Kunci : Media Tiga Dimensi, Hasil Belajar Matematika.

\section{PENDAHULUAN}

Pada hakekatnya pembelajaran merupakan proses interaksi peserta didik dengan pendidik dan sumber belajar pada suatu lingkungan belajar. Pembelajaran juga merupakan bantuan yang diberikan pendidik agar terjadi proses perolehan ilmu dan pengetahuan, pembentukan sikap dan kepercayaan serta mengarahkan kemahiran atau keterampilan kepada sesuatu yang lebih baik untuk peserta didik.

Sedangkan Pembelajaran Matematika itu sendiri merupakan suatu bimbingan dan upaya pendidik dalam membantu peserta didik untuk memiliki kompetensi dan keterampilan dalam mengatasi atau memecahkan suatu permasalahan melalui pembelajaran Matematika. Pelajaran Matematika merupakan salah satu bidang studi yang penting dalam dunia pendidikan karena dalam pelaksanaannya, tidak hanya dilakukan di semua jenjang pendidikan tetapi dari segi manfaatnya sangat membantu peserta didik dalam menyelesaikan suatu permasalahan dalam kehidupan sehari-hari.

Dalam proses pembelajaran Matematika di kelas, pendidik banyak mengalami kendala atau masalah terkait cara penyampaian materinya, karena materi-materi yang diajarkan banyak bersifat abstrak yaitu tentang konsep-konsep Matematika yang sulit dipahami peserta didik untuk itu dibutuhkan alat bantu bagi pendidik yaitu media pembelajaran dalam menyampaikan materi pelajaran.

Sesuai dengan tuntutan Kurikulum Pendidikan yang masih dipakai sekarang yaitu KTSP (Kurikulum Tingkat Satuan Pendidikan) yang menuntut peserta didik lebih aktif dalam proses pembelajaran. maka sebagai pendidik perlu melakukan perencanaan suatu 
pembelajaran mulai dari materi yang akan disampaikan hingga media pembelajaran yang terangkum dalam RPP (Rencana Pelaksanaan Pembelajaran). Menyangkut hal tersebut, maka yang menjadi perhatian peneliti adalah masalah penggunaan media pembelajaran, khususnya pada pembelajaran Matematika.

Media pembelajaran merupakan unsur penting dalam RPP yang harus ada dalam proses pembelajaran di kelas serta untuk membantu tercapainya tujuan pembelajaran. Namun melihat faktanya, Pendidik lebih mengutamakan menyampaikan materi pelajaran menggunakan metode ceramah yaitu hanya menggunakan media buku pelajaran tanpa memperhatikan perkembangan belajar peserta didik. Hal tersebut membuat peserta didik menjadi jenuh, bosan dan kurang termotivasi untuk mengikuti pelajaran. Selain itu juga, permasalahan lain yaitu pendidik sering mengabaikan pentingnya penggunaan media pembelajaran dengan berbagai alasan, antara lain yaitu terbatasnya waktu untuk membuat persiapan mengajar, sulit mencari media yang tepat atau sesuai dengan tujuan pembelajaran, tidak tersedianya biaya dan lain-lainya.

Seiring dengan perkembangan zaman, seharusnya pendidik memiliki banyak alternatif pilihan untuk menggunakan media dalam penyampaian materi pelajaran. Akan tetapi hal tersebut kurang diperhatikan oleh pendidik, khususnya pada pembelajaran Matematika yang sebagian besar materinya berisi konsep-konsep yang abstrak dan sulit untuk dipahami oleh peserta didik sehingga membutuhkan suatu media pembelajaran sebagai alat bantu untuk menyampaikan materi pelajaran. Hal tersebut berdasarkan dari pendapat $\begin{array}{lcr}\begin{array}{l}\text { Heruman } \\ \text { menyatakan } \\ \text { pembelajaran }\end{array} & \begin{array}{c}\text { (2008,1-2) } \\ \text { bahwa }\end{array} & \begin{array}{r}\text { yang } \\ \text { "Dalam }\end{array} \\ \text { Matematika yang abstrak, siswa }\end{array}$ memerlukan alat bantu berupa media, dan alat peraga yang dapat memperjelas apa yang akan disampaikan oleh guru sehingga lebih cepat dipahami dan dimengerti oleh siswa".

Melihat keadaan tersebut, tentulah berdampak pada hasil belajar peserta didik yang rata-rata kurang dari standar nilai Matematika atau KKM pada pelajaran Matematika yaitu 60. Ada 16 orang dari jumlah peserta didik di kelas IV/B mendapat nilai $<60$ dan sisanya 10 orang mendapat nilai $\geq 60$. Hal tersebut berdasarkan informasi yang diperoleh peneliti dari wali kelas IV/B SDN-3 Kereng Bangkirai.

Berdasarkan uraian masalah di atas, maka peneliti mengambil kesimpulan sementara bahwa terdapat banyak masalah dan kendala yang dihadapi pendidik pada saat pembelajaran yang salah satunya yaitu mengenai masalah penggunaan media pembelajaran khususnya pada mata pelajaran Matematika di Sekolah Dasar.

Belajar merupakan hal penting yang harus dilakukan manusia dalam kehidupan yang dinamis agar menuju kepada keadaan yang lebih baik. Adapun pengertian belajar menurut Slameto (2010:2) "Belajar ialah suatu proses usaha yang dilakukan seseorang untuk memperoleh suatu perubahan tingkah laku yang baru secara keseluruhan, sebagai hasil pengalamannya sendiri dalam interaksi dengan lingkungannya". Sedangkan menurut Djamarah (2011:13) "Belajar adalah serangkaian kegiatan jiwa raga untuk memperoleh sesuatu perubahan tingkah laku sebagai hasil dari pengalaman individu dalam interaksi dengan 
lingkungannya yang menyangkut kognitif, afektif, dan psikomotor".

Pada hakikatnya hasil belajar adalah membentuk suatu perubahan tingkah laku seseorang sebagai hasil dari proses belajarnya. Hal tersebut sejalan dengan pendapat Sudjana (2006:3) menyatakan bahwa "hasil belajar peserta didik pada hakikatnya adalah perubahan tingkah laku dan kemampuan-kemampuan yang dimiliki peserta didik setelah ia menerima pengalaman belajarnya".

Bagi peserta didik, hasil belajar merupakan hal penting yang harus dicapai pada suatu kegiatan pembelajaran di sekolah, karena hasil belajar secara tidak langsung menjadi tolak ukur apakah peserta didik mengalami proses belajar atau tidak. Hal tersebut diperkuat oleh pendapat Kunandar (2007:251), "Hasil belajar adalah kemampuan peserta didik dalam memenuhi suatu tahapan pencapaian pengalaman belajar dalam satu kompetensi belajar".

Kata Media berasal dari "Medius" yang secara harfiah artinya tengah atau pengantar. Menurut Asnawir dan Usman (2002:11) "Media merupakan sesuatu yang bersifat menyalurkan pesan dan dapat merangsang pikiran, perasaan, dan kemauan audien (peserta didik) sehingga dapat mendorong terjadinya proses belajar pada dirinya". Hal tersebut senada dengan pendapat, Djamarah dan Zain (2010:121) "Media adalah alat bantu apa saja yang dapat dijadikan sebagai penyalur pesan guna mencapai tujuan pembelajaran.

Menurut pendapat Jennah (2009:46) "media tiga dimensi adalah media yang berbentuk isi atau (volume) memiliki ukuran panjang, lebar, dan tinggi, atau media yang dalam bentuk model". Sedangkan menurut Daryanto (2010:29) "Media tiga dimensi adalah sekelompok media tanpa proyeksi yang penyajiannya secara visual tiga dimensional. Kelompok media ini dapat berwujud sebagai benda asli baik hidup maupun mati, dan dapat pula berwujud sebagai tiruan yang mewakili as linya".

Playdough merupakan media tiga dimensi non proyektable berjenis model yang edukatif dan menarik dalam pembelajaran, karena peserta didik bisa belajar sambil bermain sehingga membuat suasana belajar menjadi menarik dan menyenangkan. Hal tersebut berdasarkan pendapat dari Einon (Setianingsih, 2011) yang menyatakan bahwa "playdough merupakan material sehari-hari yang paling baik untuk membuat mode1/bentuk bagi seorang anak". Selanjutnya Novitasari (2009) memperjelas lagi mengenai jenis media playdough yaitu "...dalam menjelaskan materi hendaknya guru menggunakan media berupa model seperti playdough, melalui media ini materi yang dije laskan tidak lagi bersifat abstrak sehingga siswa dapat memahami materi tersebut".

\section{METODOLOGI}

Penelitian ini dilaksanakan di Sekolah Dasar Negeri-3 Kereng Bangkirai untuk mata pelajaran Matematika kelas IV/B. Lokasi penelitian terletak di Jalan Panenga V (RTA Milono km.8) Kecamatan Sebangau. Adapun alasan peneliti dalam memilih sekolah tersebut menjadi tempat penelitian yaitu karena peneliti menemukan fenomena atau permasalahan di sekolah tersebut dan membuat peneliti menjadi tertarik untuk meneliti dan mencoba untuk memecahkan dan mengatasi permasalahan yang sedang dihadapi.

Penelitian ini merupakan Penelitian Tindakan Kelas (Classroom action research). Menurut Kunandar (2011:42) "Penelitian Tindakan Kelas merupakan bagian dari penelitian tindakan (action research), dan penelitian tindakan ini 
bagian dari penelitian pada umumnya". Sedangkan menurut Suharsimi Arikunto (2012:58) "Penelitian Tindakan Kelas adalah penelitian tindakan (action research) yang dilakukan dengan tujuan memperbaiki mutu praktik pembelajaran di kelasnya". Penelitian Tindakan Kelas ini berfokus pada upaya untuk mengubah kondisi sekarang ke arah kondisi yang diharapkan. Penelitian ini juga dilakukan untuk melihat penggunaan media tiga dimensi pada pembelajaran Matematika untuk meningkatkan hasil belajar peserta didik kelas IV/B SDN-3 Kereng Bangkirai.

\section{Gambar 1. Sik lus PTK}

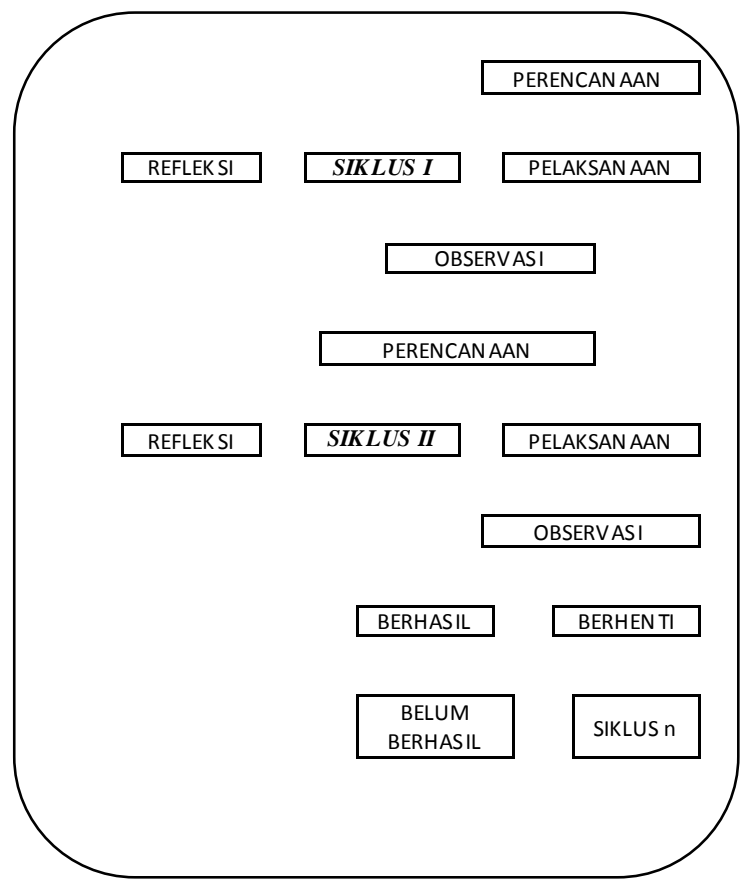

Teknik pemberian tes dilakukan untuk mengukur kemampuan peserta didik apakah mengalami peningkatan pada pemahaman tentang apa yang diajarkan. Teknik tes yang dilakukan peneliti menggunakan tes tertulis dalam bentuk isian.

Tes tertulis ini diberikan sebelum penelitian tindakan kelas dilakukan atau tes pra tindakan dan pada saat tindakan pembelajaran siklus I dan siklus II berakhir. Tes yang diberikan sebelum penelitian tindakan kelas untuk mengetahui sejauh mana pemahaman peserta didik terhadap materi bilangan pecahan. Sedangkan tes yang diberikan pada saat pembelajaran siklus I dan II berakhir untuk mengetahui sejauh mana kemampuan dan pemahaman peserta didik terhadap bilangan pecahan dengan menggunakan media tiga dimensi pada pembelajaran siklus I dan siklus II.

Menurut Sukardi (2005:122) "Validitas suatu instrumen penelitian merupakan derajat yang menunjukkan dimana suatu tes mengukur apa yang hendak diukur". Hal tersebut sependapat dengan Sugiyono (2007:172) "bahwa valid berarti instrumen tersebut dapat digunakan untuk mengukur apa yang seharusnya diukur". Sedangkan Riduwan (2007:97) lebih menyederhanakan lagi "bahwa valid itu mengukur apa yang hendak diukur (ketepatan)".

\section{HASIL DAN PEMBAHASAN}

Tes pra tindakan atau tes awal ini bertujuan untuk mengetahui kemampuan awal peserta didik terhadap materi bilangan pecahan sebelum memasuki tahap pemberian tindakan. Hasil tes pra tindakan ini akan menjadi tolak ukur keberhasilan terhadap pembelajaran yang akan dilakukan. Soal tes yang diberikan berjumlah 17 butir soal dalam bentuk isian. Data hasil tes pra tindakan tersebut disajikan dalam tabel sebagai berikut :

Tabel 1. Hasil Pra Tindakan

\begin{tabular}{|c|c|c|c|c|}
\hline \multirow[b]{2}{*}{ No } & \multirow{2}{*}{$\begin{array}{c}\text { Inisial } \\
\text { Peserta } \\
\text { Didik }\end{array}$} & \multicolumn{3}{|c|}{ Nilai Tes Hasil B elajar } \\
\hline & & $\begin{array}{c}\text { Tes Pra } \\
\text { Tindak } \\
\text { an }\end{array}$ & Siklus I & Siklus II \\
\hline 1 & $\mathrm{Te}$ & 47,06 & 58,82 & 100,00 \\
\hline 2 & $\mathrm{~S}$ & 64,71 & 70,59 & 100,00 \\
\hline 3 & $\overline{\text { ANJ }}$ & 41,18 & 58,82 & 88,24 \\
\hline 4 & $\overline{\mathrm{DE}}$ & 29,41 & 41,18 & 70,59 \\
\hline 5 & $\mathrm{~K}$ & 41,18 & 58,82 & 88,24 \\
\hline 6 & $\mathrm{~J}$ & 29,41 & 58,82 & 64,71 \\
\hline 7 & MIG & 70,59 & 88,24 & 100,00 \\
\hline
\end{tabular}




\begin{tabular}{|c|c|c|c|c|}
\hline 8 & YP & 41,18 & 70,59 & 100,00 \\
\hline 9 & MRA & 29,41 & 58,82 & 64,71 \\
\hline 10 & \begin{tabular}{|l|} 
IS \\
\end{tabular} & 47,06 & 70,59 & 100,00 \\
\hline 11 & \begin{tabular}{|l|}
$T$ \\
\end{tabular} & 29,41 & 58,82 & 88,24 \\
\hline 12 & $P$ & 58,82 & 82,35 & 100,00 \\
\hline 13 & $\mathrm{HW}$ & 29,41 & 58,82 & 88,24 \\
\hline 14 & MD & 58,82 & 70,59 & 100,00 \\
\hline 15 & \begin{tabular}{|l|}
$\mathrm{OP}$ \\
\end{tabular} & 41,18 & 58,82 & 88,24 \\
\hline 16 & R & 47,06 & 70,59 & 100,00 \\
\hline 17 & \begin{tabular}{|l|} 
MI \\
\end{tabular} & 47,06 & 58,82 & 100,00 \\
\hline 18 & $\mathrm{~N}$ & 70,59 & 88,24 & 100,00 \\
\hline 19 & \begin{tabular}{|c|} 
JRM \\
\end{tabular} & 29,41 & 47,06 & 70,59 \\
\hline 20 & $\operatorname{Re}$ & 29,41 & 58,82 & 100,00 \\
\hline 21 & RP & 58,82 & 76,47 & 100,00 \\
\hline 22 & \begin{tabular}{|l|}
$\mathrm{Tr}$ \\
\end{tabular} & 47,06 & 70,59 & 100,00 \\
\hline 23 & AM & 47,06 & 76,47 & 100,00 \\
\hline 24 & A & 58,82 & 70,59 & 100,00 \\
\hline 25 & \begin{tabular}{|l|}
$\mathrm{RH}$ \\
\end{tabular} & 47,06 & 76,47 & 100,00 \\
\hline 26 & $\mathrm{~V}$ & 41,18 & 58,82 & 88,24 \\
\hline \multicolumn{2}{|r|}{ Jumlah } & 1182,36 & 1717,63 & 2400,04 \\
\hline & Rata-rata & 45,48 & 66,06 & 92,31 \\
\hline
\end{tabular}

Berdasarkan tabel di atas, dapat diketahui peningkatan rata-rata nilai hasil belajar peserta didik kelas IV/B SDN-3 Kereng Bangkirai pada setiap siklusnya. Adapun peningkatan rata-rata nilai hasil belajar peserta didik siklus I yang diambil berdasarkan rata-rata nilai hasil tes pra tindakan peserta didik yaitu dari 45,48 menjadi 66,06 atau mengalami peningkatan nilai rata-rata sebanyak 20,58. Sedangkan peningkatan rata-rata nilai hasil belajar peserta didik siklus II yang diambil berdasarkan rata-rata nilai hasil belajar siklus I yaitu dari 66,06 menjadi 92,31 atau mengalami peningkatan nilai rata-rata sebanyak 26,25 .

Dengan demikian, hipotesis tindakan yang berbunyi : Penggunaan media tiga dimensi dapat meningkatkan hasil belajar Matematika peserta didik kelas IV SDN-3 Kereng Bangkirai Palangkaraya tahun pelajaran 2012/2013 dapat diterima dan dibuktikan kebenarannya.

\section{PENUTUP}

Hasil penelitian, dapat disimpulkan bahwa penggunaan media tiga dimensi pada mata pelajaran Matematika dapat meningkatkan hasil belajar peserta didik kelas IV/B SDN-3 Kereng Bangkirai tahun pelajaran 2012/2013.

Peningkatan kemampuan dan pemahaman peserta didik pada pelajaran matematika dapat dilihat dari hasil belajar siklus I yaitu rata-rata nilainya mencapai 66,06 dan pada siklus II nilai rata-rata peserta didik meningkat menjadi 92,31. Oleh karena itu, penggunaan media tiga dimensi merupakan salah satu penunjang keberhasilan dalam mencapai tujuan pembelajaran dilihat dari hasil belajar yang diperoleh peserta didik kelas IV/B SDN-3 Kereng Bangkirai.

Berdasarkan hasil penelitian yang dilakukan maka dapat diberikan saran sebagai berikut :

1. Bagi kepala sekolah, diharapkan menyarankan guruguru untuk menerapkan atau menggunakan media pembelajaran dalm kegiatan belajar mengajar agar peserta didik menjadi semangat dalam mengikuti pelajaran dan tujuan pembelajaran pun dapat tercapai dengan maksimal.

2. Bagi pendidik, diharapkan pada saat memilih dan menggunakan media pembelajaran agar memperhatikan kesesuaian media dengan tujuan pembelajaran serta kesesuaian dengan penggunaan metode pembelajarannya agar media pembelajaran tersebut dapat dimanfaatkan secara maksimal.

3. Bagi peserta didik, melalui penggunaan media pembelajaran diharapkan untuk 

bisa menunjukkan segala kompetensinya dalam pembelajaran agar terjadi pembelajaran yang efektif sehingga kompetensi yang dimiliki peserta didik dapat berkembang.

4. Bagi peneliti sendiri, hendaknya dalam penggunaan media tiga dimensi tidak hanya diterapkan pada pelajaran Matematika, tetapi juga diterapkan pada pelajaran lainnya ketika peneliti mengajar. Selain itu juga peneliti diharapkan untuk terus menggali pengetahuan mengenai penggunaan media pembelajaran.

\section{DAFTAR PUSTAKA}

Anom, (2006), Peningkatan Hasil Belajar SAINS Melalui Model Pembelajaran Kooperatif, Skripsi Universitas Palangkaraya.

Aqib, Z., (2011), Penelitian Tindakan Kelas untuk Guru SD, SLB, dan TK, Bandung : CV. Yrama Widya.

Asrori, M., (2007), Penelitian Tindakan Kelas, Bandung : CV. Wacana Prima.

Asnawir dan Usman, B., (2002), Media Pembelajaran, Jakarta : Ciputat Pers.

Daryanto, (2010), Media Pembelajaran, Yogyakarta: Gava Media.

Djamarah, S.B., (2011), Psikologi Belajar, Jakarta : PT. Rineka Cipta.

Djamarah, S.B., dan Zain, A., (2010), Strategi Belajar Mengajar, Jakarta: PT. Rineka Cipta.
Frentino, (2012), Peningkatan Hasil

Belajar Melalui Media Konkret Pada

Pokok Bahasan Satuan-Satuan Waktu,

Skripsi Universitas Muhammadiyah Palangkaraya.

Hamalik, O., (2011), Proses Belajar

Mengajar, Bandung : PT. Bumi Aksara.

Heruman, (2008), Model Pembelajaran

Matematika Di Sekolah Dasar, Bandung : PT. Remaja Rosdakarya.

Jennah, R., (2009), Media Pembelajaran, Banjarmasin : Antasari Press.

Karso, dkk, (2007), Pendidikan

Matematika I, Jakarta : Universitas

Terbuka.

Kunandar, (2007), Guru Profesional, Jakarta : PT. Raja Grafindo Persada.

Kunandar, (2011), Langkah Mudah

Penelitian Tindakan Kelas Sebagai Pengembangan Profesi Guru, Jakarta : PT. Raja Grafindo Persada.

Muhibbin Syah, (2011), Psikologi Belajar, Jakarta : PT. Raja Grafindo Persada.

Novitasari, N., (2009), Efektivitas Media

Playdough Untuk Meningkatkan Prestasi Belajar Materi Gunung Berapi

Dalam Mata Pelajaran IPA, Skripsi Universitas Pendidikan Indonesia

Rachmawati, Y., dan Kurniati, E., (2005), Strategi Pengembangan Kreativitas Pada Anak Usia Dini, Jakarta :

Depdiknas.

Riduwan, (2007), Belajar Mudah Penelitian Untuk Guru, Karyawan Dan Peneliti Pemula, Bandung :

Alfabeta. 
Santyasa, (2007), Metodelogi Penelitian

Tindakan Kelas, Singaraja : Universitas

Pendidikan Ganesha.

Setianingsih, Y.L., (2011), Pengaruh

Media Playdough Terhadap Kreativitas

Anak Usia Taman Kanak-Kanak, Skripsi

Universitas Pendidikan Indonesia.

Slameto, (2010), Belajar Dan Faktor-

Faktor Yang Mempengaruhinya, Jakarta :

PT. Rineka Cipta.

Sudjana, N., (2006), Penilaian Hasil

Proses Belajar Mengajar, Bandung : PT.

Remaja Rosdakarya.

Sudjana, N., dan Rivai, A., (2002), Media

Pembelajaran, Bandung : Sinar Baru

Algensindo.

Sugiyono, (2007), Metode Penelitian

Pendidikan Pendekatan Kuantitatif,

Kualitatif, $\quad$ dan $R \& D$, Bandung :

Alfabeta.

Sugiyono, (2012), Metode Penelitian

Pendidikan, Bandung : Alfabeta.

Suharsimi Arikunto, (2006), Prosedur Penelitian Suatu Pendekatan Praktik, Jakarta : PT. Rineka Cipta.

Suharsimi Arikunto, (2010), Prosedur Penelitian Suatu Pendekatan Praktik, Jakarta : $\quad$ PT. Rineka Cipta.

Suharsimi Arikunto, (2012), Penelitian Tindakan Kelas, Jakarta : PT. Bumi Aksara.

Sukardi, (2005), Metodologi Penelitian Pendidikan Kompetensi dan Praktiknya, Jakarta : PT. Bumi Aksara.
Sukardi, (2012), Metodologi Penelitian

Pendidikan Kompetensi dan Praktiknya, Jakarta : PT. Bumi Aksara.

Suryabrata, S., (2006), Metodologi

Penelitian, Jakarta : PT. Raja Grafindo

Persada.

Yamin, M., (2008), Desain Pembelajaran Berbasis Tingkat Satuan Pendidikan, Jakarta : Gaung Persada Press. 